RESEARCH PAPER

\title{
Development and Quality Evaluation of Multigrains Idli
}

\author{
Adsare A.D. ${ }^{*}$, Giram K.K. ${ }^{2}$, Kadbhane V.S. ${ }^{3}$, Khupase S.P. ${ }^{4}$ and John Devid ${ }^{5}$
}

1SRA College of Food Technology Ashti, Beed, Maharashtra, India ${ }^{2} \mathrm{Ph} . \mathrm{D}$ Scholar, SHAUTS Prayagraj, Uttar Pradech, India

3SRA College of Food Technology Ashti, Beed, Maharashtra, India ${ }^{4}$ Ph.D Scholar, SHAUTS Prayagraj, Uttar Pradech, India

${ }^{5}$ Professor Dean, WCDT, SHAUTS Prayagraj, Uttar Pradech, India

*Corresponding author: adsareabhijeet1@gmail.com

Paper No.: 247

Received: 19-09-2020

Revised: $17-11-2020$

Accepted: $12-12-2020$

\begin{abstract}
Cereals and pulses combination was good nutritional sources of fiber, protein and energy. This research was conducted determining the physio-chemical properties and organoleptic evaluation of developed multigrain idli. Idli was prepared from Sorghum, Pearl millet, Finger millet, Amaranth and Black gram. All the ingredient for preparation of $i d l i$ was collected from the Krushi exhibition, farmer and local market. Formulation carried out by CRD method. Four different types of $i d l i$ with varying proposition of ingredients was prepared. The composition was $\mathrm{T}_{0}$ - rice $70 \mathrm{gm}$ and black gram $30 \mathrm{gm}, \mathrm{T}_{1}$ sorghum: pearl millet: finger millet: amaranth: black gram; 55:5:5:5:30; $\mathrm{T}_{2}-$ 45:10:10:5:30; T3-35:15:10:10:30 respectively. These scores compared with standard idli. The quality evaluation of developed idli samples such as organoleptic evaluation and physio-chemical parameters. The organoleptic score and physio-chemical parameters of $\mathrm{T}_{3}$ sample better than other samples. The proximate evaluation of developed idli samples such as $\mathrm{T}_{3}$ sample was rich in fiber, protein, calcium, iron and cheap in carbohydrate and fat. The overall evaluations $\mathrm{T}_{3}$ sample was better than $\mathrm{T}_{0^{\prime}} \mathrm{T}_{1}$ and $\mathrm{T}_{2}$.
\end{abstract}

Keywords: Idli, Physical, Chemical, Organoleptic, Amaranth

Idli was famous traditional indigenous fermented food consumed throughout India and other countries. This was prepared by steaming a fermented black gram and rice batter. It was important contribution to the diet as a source of protein, calories and vitamins. After cooking idli was prepared soft and spongy texture. It was easy to digestible and good nutritive value.

Different types of $i d l i$ were prepared in India such as standard $i d l i$, rava idli, Kancheepuram idli, stuffed idli, ragi idli and curd idli. Idli was served with sambar and different variety of chutney such as coconut chutney, onion chutney and mint chutney.

The complete or partial replacing of rice with sorghum wasbest effect on the nutritive value by increasing the fat, fibre, protein, calcium and iron content in the developed multigrain idli. Pearl millet was a principal source of energy, vitamins, protein and minerals.

Finger millet (ragi) was rich in protein, iron, calcium, phosphorus, fibre and vitamin content. It provides highest level of antioxidants properties, phytochemicals, which make it easy and slowly digestible. Hence it helps to control blood glucose levels in diabetic patients. Amaranth content best quality protein. The "protein complement" of grain

How to cite this article: Adsare, A.D., Giram, K.K., Kadbhane, V.S., Khupase, S.P. and Devid, J. (2020). Development and Quality Evaluation of Multigrains Idli. Int. J. Food Ferment. Technol., 10(2): 95-100.

Source of Support: None; Conflict of Interest: None 
amaranth was very near to the levels recommended by $\mathrm{FAO} / \mathrm{WHO}$. Black gram has a mucilaginous material which makes it a valuable ingredient in Idli preparation. The chief proteins present in black gram such as albumins, globulins and glutelins. This mucilaginous material helps to hold the carbon dioxide during fermentation.

\section{MATERIALS AND METHODS}

The methodology adopted has been described under the following headings process flow chart for preparation.

\section{Raw Material}

Selection of good quality and specific variety of raw material from the market such as Sorghum, Pearl Millet, Finger millet, Amaranth, Black Gram for the preparation of Idli.

Table 1: Raw Material Variety

\begin{tabular}{lll}
\hline Sl. No. & Ingredients & Varieties \\
\hline 1 & Sorghum & Dagdi M-35-1 \\
2 & Pearl Millet & Ganga kaveri-1111 \\
3 & Finger millet & Ragi ML-365 \\
4 & Amaranth & Pusalal chaulai \\
5 & Black Gram & Plant U 30 \\
\hline
\end{tabular}

\section{Formulation of Idli}

Completely randomized designs (CRD)were used for the formulation of $i d l i$. The four different types of $i d l i$ with different proportion of ingredients were prepared and the composition is given in the Table 2.

Table 2: Formulation of $i d l i$

\begin{tabular}{|c|c|c|c|c|}
\hline \multirow[b]{2}{*}{ Ingredients } & \multicolumn{4}{|c|}{ Sample } \\
\hline & $\begin{array}{c}\mathrm{T}_{0} \\
\text { (Control) }\end{array}$ & $-T_{1}$ & $\mathrm{~T}_{2}$ & $\mathbf{T}_{3}$ \\
\hline Sorghum (gm) & - & 55 & 45 & 35 \\
\hline Pearl Millet (gm) & - & 5 & 10 & 15 \\
\hline Finger millet (gm) & - & 5 & 10 & 10 \\
\hline Amaranth (gm) & - & 5 & 5 & 10 \\
\hline Rice (gm) & 70 & - & - & - \\
\hline Black Gram (gm) & 30 & 30 & 30 & 30 \\
\hline
\end{tabular}

\section{Preparation of $i d l i$}

The all ingredients on different proportion were soaked in 2 to $5 \mathrm{hrs}$ and after soaking Sorghum, pearl millet, finger millet and amaranth were ground coarse and black gram to a fine paste. This paste was mixed together and added of salt. Obtained batter was allowed to ferment for 14 hours after that it was poured in an idli steamer and steamed till it for 24 min in medium flame and finally idli was done.

\section{Flow chart for preparation of $i d l i$}

Sorghum, Pearl millet, Finger millet and Amaranth
$\downarrow$
Black gram dhal
$\downarrow$
Wash and soak separately for 5 hrs Wash and
soak for 2 hrs
$\downarrow$
Grind coarsely grind finely
$\downarrow$
Paste was mixed together and mix well
$\downarrow$
Add salt (1-3\%)
$\downarrow$
Fermentation for 14 hrs in room temperature
$\downarrow$
Pour batter in idli mold
$\downarrow$
Steam for $22-24$ minutes
$\downarrow$

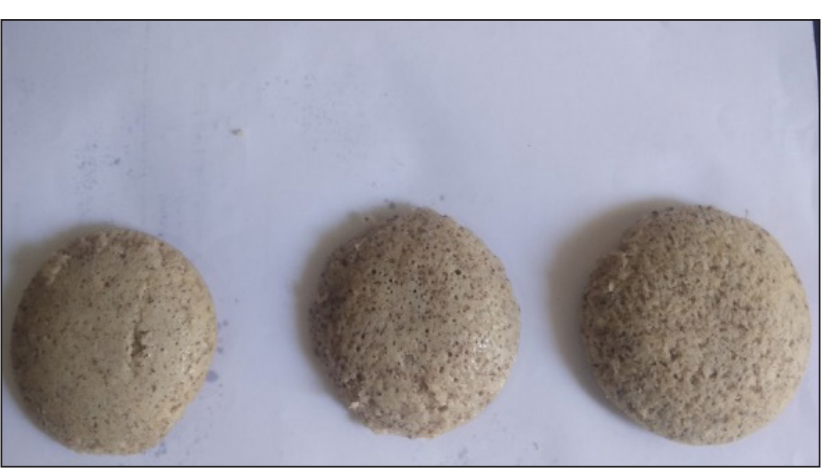

Fig. 1: Prepared Sample of Multigrain idli 


\section{RESULTS AND DISCUSSION}

Proximate evaluation of raw material used for idli preparation

The Physico-chemical properties of raw materials were analyzed to check the quality of final product. The nutritional composition of Sorghum, Pearl millet, Finger millet, Amaranth and Black gram given in table 3 .

\section{Proximate evaluation of Developed $i d l i$}

The nutritive value of the developed multigrain based idli is presented in table 4 .

\section{Organoleptic evaluation of Multigrain idli}

The sensory evaluation of idli was determined by using a taste panel. This taste panel is a semi-trained panel using nine-point hedonic scale. By this rating score sample no. T3 has been found best with scoring of 38.05 marks. The acceptability statements and their marks given in table 5 .

\section{Physical Parameters of Multigrain idli}

Various physical parameters of developed idli determined \& compare with standard idli such as diameter, thickness, weight, fermentation time and time taken for complete steaming.

\section{Microbial analysis of Multigran idli}

In microbial analysis Yeast and mould count was observed to be $15 \times 10^{4} \mathrm{cfu} / \mathrm{g}$ in control idli at zero day, on first day it was observed $24 \times 10^{4} \mathrm{cfu} / \mathrm{g}$ and on second day it was $45 \times 10^{4} \mathrm{cfu} / \mathrm{g}$ respectively. Total plate Counts (TPC) was observed to be $8 \times 10^{4} \mathrm{cfu} / \mathrm{g}$

Table 3: Proximate analysis of raw material used for $i d l i$

\begin{tabular}{|c|c|c|c|c|c|c|c|}
\hline \multirow{2}{*}{ S1. No. } & \multirow{2}{*}{ Sample } & \multicolumn{6}{|c|}{ Parameter (\%) } \\
\hline & & Moisture & Ash & Fat & Fiber & Protein & Carbohydrate \\
\hline 1 & Sorghum & 8.37 & 1.44 & 3.60 & 6.15 & 11.90 & 74.69 \\
\hline 2 & Pearl millet & 9.46 & 1.50 & 4.78 & 1.24 & 10.36 & 73.89 \\
\hline 3 & Finger millet & 11.60 & 2.08 & 2.24 & 3.81 & 7.24 & 73.03 \\
\hline 4 & Amaranth & 8.54 & 2.24 & 5.24 & 5.12 & 11.32 & 67.54 \\
\hline 5 & Black gram & 9.59 & 3.45 & 2.60 & 18.62 & 24.85 & 59.51 \\
\hline
\end{tabular}

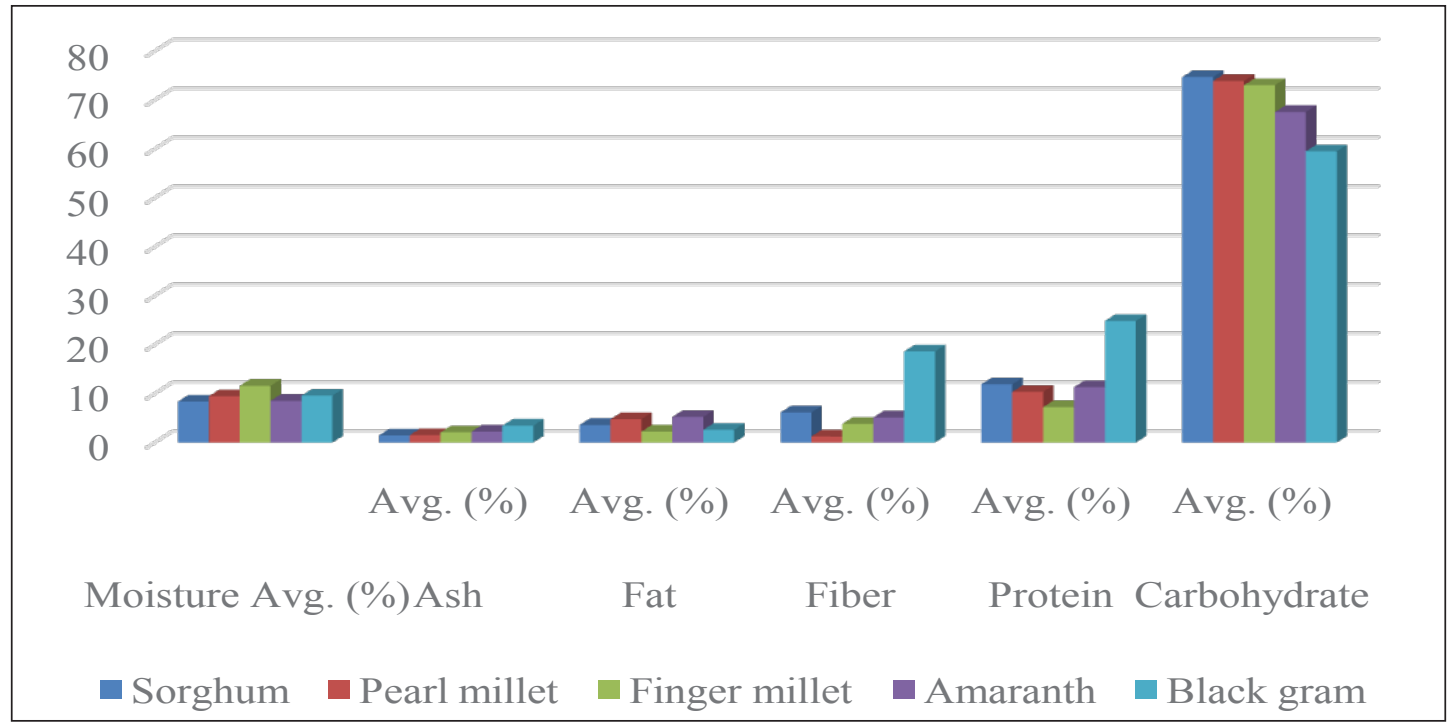

Fig. 2: Proximate analysis of raw material 
Table 4: Nutritive value of the developed idli per $100 \mathrm{gm}$

\begin{tabular}{|c|c|c|c|c|c|c|c|}
\hline \multirow{2}{*}{ Parameter } & \multicolumn{4}{|c|}{ Sample } & \multirow{2}{*}{ Std. Dev. } & \multirow{2}{*}{ Mean } & \multirow{2}{*}{$\mathrm{CV} \%$} \\
\hline & $\mathrm{T}_{0}$ & $\mathrm{~T}_{1}$ & $T_{2}$ & $T_{3}$ & & & \\
\hline Moisture & 63.45 & 64.92 & 62.96 & 62.90 & 0.80 & 63.82 & 1.25 \\
\hline Ash & 1.59 & 1.70 & 1.82 & 1.84 & 0.11 & 1.73 & 6.68 \\
\hline Fat & 0.86 & 0.85 & 0.78 & 0.73 & 0.10 & 0.87 & 12.39 \\
\hline Protein & 7.0 & 8.75 & 9.01 & 9.10 & 0.98 & 8.46 & 11.67 \\
\hline Carbohydrate & 31.50 & 21.30 & 22.46 & 21.06 & 5.0 & 24.03 & 20.83 \\
\hline Fiber & 1.17 & 2.50 & 2.90 & 2.90 & 0.82 & 2.36 & 34.64 \\
\hline Calcium & 25.0 & 40.86 & 46.42 & 50.51 & 11.18 & 40.69 & 27.48 \\
\hline Iron & 3.25 & 3.08 & 3.52 & 3.57 & 0.53 & 3.03 & 17.75 \\
\hline
\end{tabular}

All values are means $\pm S D$ of the triplicate, $C V \%=$ Coefficient of Variance.

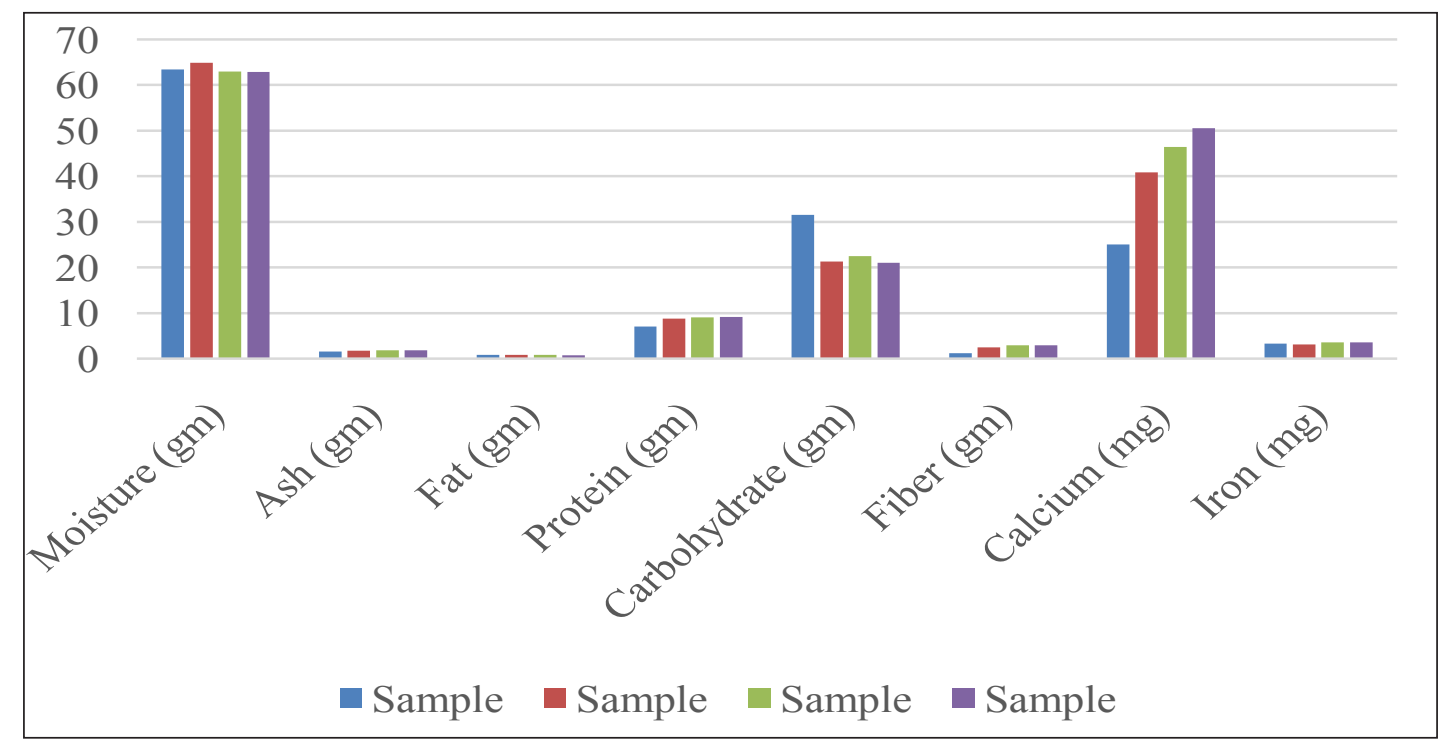

Fig. 3: Proximate Analysis of Developed idli

Table 5: Organoleptic Scores of Multigrain idli

\begin{tabular}{llllll}
\hline \multirow{2}{*}{ Sample } & \multicolumn{5}{c}{ Parameter } \\
\cline { 2 - 6 } & Colour & Texture & Flavour & Taste & Over all acceptability \\
\hline $\mathrm{T}_{0}$ & 7.1 & 7.2 & 7.1 & 7.8 & 7.30 \\
$\mathrm{~T}_{1}$ & 7.7 & 8 & 6.9 & 6.8 & 7.35 \\
$\mathrm{~T}_{2}$ & 6.9 & 8.3 & 7.3 & 7.4 & 7.49 \\
$\mathrm{~T}_{3}$ & 7.1 & 8.3 & 7.1 & 7.8 & 7.57 \\
\hline Std. Dev. & 0.34 & 0.51 & 0.16 & 0.47 & 0.12 \\
\hline Mean & 7.2 & 7.95 & 7.1 & 7.45 & 7.42 \\
\hline CV\% & 4.81 & 6.53 & 2.29 & 6.34 & 1.67 \\
\hline
\end{tabular}

All values are means $\pm S D$ of the triplicate, $C V \%=$ Coefficient of Variance.

to zero day, on first day it was observed $15 \times 10^{4} \mathrm{cfu} / \mathrm{g}$ and second day it was $25 \times 10^{4} \mathrm{cfu} / \mathrm{g}$ respectively. The E. coli count was not detected in anyof the formulated multigrain idli on any of the storage days. The microbiological analysis of multigrain idli at different storage period showed that the total plate counts and yeast and mould count increased with increase in storage period. 


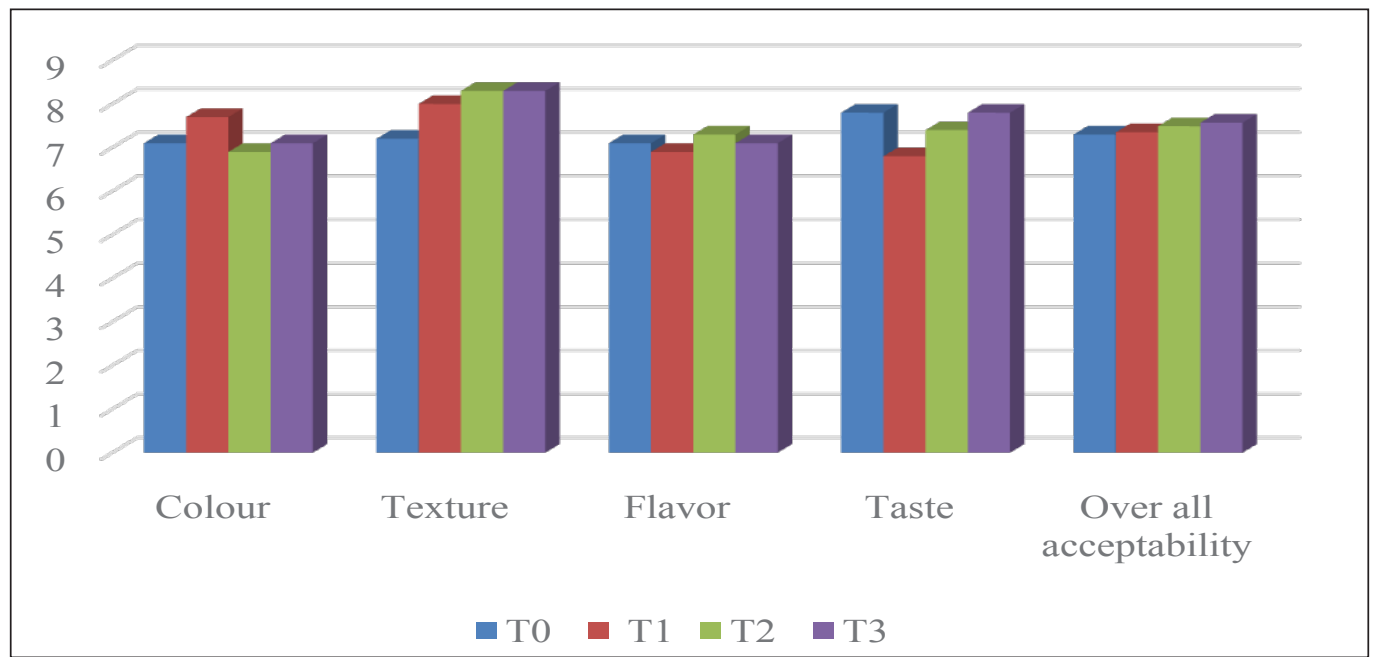

Fig. 4: Organoleptic Scores of Multigrain idli

Table 6: Physical Parameters of Multigrain idli

\begin{tabular}{|c|c|c|c|c|c|c|c|}
\hline \multirow{2}{*}{ Parameter } & \multicolumn{4}{|c|}{ Sample } & \multirow{2}{*}{ Std. Dev. } & \multirow{2}{*}{ Mean } & \multirow{2}{*}{$\mathrm{CV} \%$} \\
\hline & $\mathrm{T}_{0}$ & $\mathrm{~T}_{1}$ & $\mathrm{~T}_{2}$ & $\mathrm{~T}_{3}$ & & & \\
\hline Diameter (cm) & 7.2 & 7.2 & 7.2 & 7.3 & 0.05 & 7.22 & 0.69 \\
\hline Thickness (cm) & 1.8 & 1.7 & 1.9 & 2.1 & 0.17 & 1.87 & 9.1 \\
\hline Cooking weight of $i d l i(\mathrm{gm})$ & 39.5 & 39.8 & 40.1 & 44.5 & 2.5 & 40.8 & 6.14 \\
\hline Cooking time (min) & 24 & 24 & 24 & 24 & 0 & 24 & 0 \\
\hline Fermentation time (hrs.) & 14 & 14 & 14 & 14 & 0 & 14 & 0 \\
\hline
\end{tabular}

All values are means $\pm S D$ of the triplicate, $C V \%=$ Coefficient of Variance.

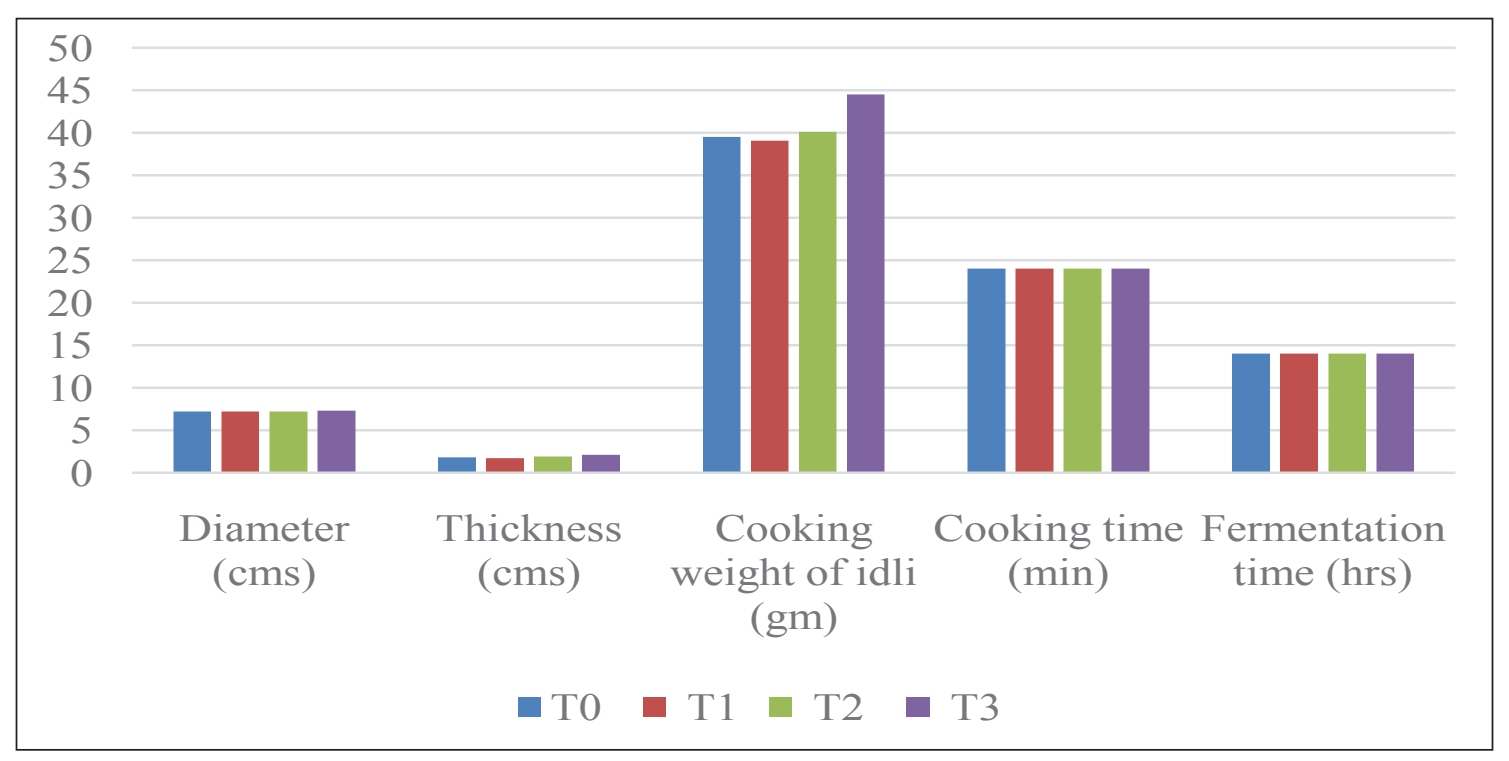

Fig. 5: Physical Parameters of Multigrain idli 
Table 7: Microbial analysis of idli

\begin{tabular}{|c|c|c|c|c|c|c|}
\hline \multirow[b]{2}{*}{ Parameters } & \multirow{2}{*}{$\begin{array}{l}\text { Storage pe- } \\
\text { riod (Days) }\end{array}$} & \multicolumn{5}{|c|}{ Sample } \\
\hline & & $\begin{array}{c}\text { T0 } \\
\text { Control }\end{array}$ & $\mathbf{T}_{1}$ & $\mathbf{T}_{2}$ & $\mathbf{T}_{3}$ & $\mathbf{T}_{4}$ \\
\hline \multirow{4}{*}{$\begin{array}{l}\text { Yeast and Mould } \\
(\mathrm{cfu} / \mathrm{g} \mathrm{10})\end{array}$} & 0 & 15 & 12 & 13 & 16 & 12 \\
\hline & 1 & 24 & 22 & 20 & 25 & 23 \\
\hline & 2 & 45 & 41 & 44 & 43 & 40 \\
\hline & 3 & TNTC & TNTC & TNTC & TNTC & TNTC \\
\hline \multirow{4}{*}{$\begin{array}{l}\text { Total Plate Count } \\
(\mathrm{cfu} / \mathrm{g} \mathrm{10})\end{array}$} & 0 & 8 & 7 & 9 & 6 & 8 \\
\hline & 1 & 15 & 13 & 16 & 18 & 14 \\
\hline & 2 & 25 & 24 & 29 & 22 & 23 \\
\hline & 3 & TNTC & TNTC & TNTC & TNTC & TNTC \\
\hline \multirow{4}{*}{$\begin{array}{l}\text { E. coli count } \\
\left(\mathrm{cfu} / \mathrm{g} 10^{4}\right)\end{array}$} & 0 & ND & ND & ND & ND & ND \\
\hline & 1 & ND & ND & ND & ND & ND \\
\hline & 2 & ND & ND & ND & ND & ND \\
\hline & 3 & ND & ND & ND & ND & ND \\
\hline
\end{tabular}

${ }^{*}$ CFU-Colony Forming Unit, TNTC- Too Numerous to Count, ND- Not Detected.

\section{CONCLUSION}

The cereal and legume were blends especially high fiber and protein sources. Complete replacing of rice with multigrain was good impact on the nutritive value by increasing the protein, fat, fiber, calcium and iron content in the developed multigrain idli. The quality evaluation of developed multigrain idli samples such as organoleptic evaluation and physio-chemical parameters. The organoleptic score and physical parameters were $\mathrm{T}_{3}$ sample better than other samples. The quality evaluation of developed multigrain idli $\mathrm{T}_{3}$ sample was rich in fiber, protein, calcium, iron and less in carbohydrate and fat. The overall analysis of $\mathrm{T}_{3}$ sample was better than $\mathrm{T}_{0^{\prime}} \mathrm{T}_{1}$ and $\mathrm{T}_{2}$.

\section{REFERENCES}

Ankuzo, H. et al. 2011. Beneficial effect of the leaves of Murraya koenigii (Linn.) Spreng (Rutaceae) on diabetes-induced renal damage in vivo. J. Ethnopharmacol., 135: 88-942.

Balasubramanian, S. and Viswanathan, R. 2007. Properties of idli Batter During its Fermentation Time. J. Food Proces. Preserv., 31(1): 32-40.
Nazni, P. and Shalini, S. 2010. Physical and nutritional evaluation of idli prepared from sorghum. Asian J. Sci. Tech., 2: 044-048.

Nazni, P. and Shalini, S. 2010. Standardization and quality evaluation of idli prepared from pearl millet (Pennisetum glaucum). Int. J. Curr. Res., 5: 84-87.

Nisha et al. 2005. Effect of stabilizers on stabilization of idli (traditional south Indian food) batter during storage, Food Hydrocolloids, 19: 179-186.

Reddy, N.R et al. 1982. Legume based fermented foods: Their preparation and nutritional quality. CRC Critical Review 1 in Food Science and Nutrition, 17: 335-370.

Reddy, N.R. and Salunkhe, D.K. 1980. Effect of fermentation of phytate phosphorous, and mineral content in black gram, rice and black gram and rice blends. J. Food Sci., 45: 17081712.

Soni, S.K. and Sandhu, D.K. 1989. Fermentation of idli: Effects of changes in raw materials and physico-chemical conditions. J. Cereal Sci., 10: 227-238.

Soni, S.K. and Sandhu, D.K. 1990. Indian fermented foods: Microbiological and biochemical aspects. Indian J. Microb., 30(2): 135-157.

Sridevi, J. et al. 2010. Selection of starter cultures for idli batter fermentation and their effect on quality of idlis. J. Food Sci. Technol., 47: 557-563. 